\title{
An Update on Biology, Extent of Damage and Effective Management Strategies of Chickpea Pod Borer (Helicoverpa armigera)
}

\author{
Muhammad Tariq Mahmood ${ }^{1 *}$, Muhammad Akhtar ${ }^{2}$, Mushtaq Ahmad ${ }^{1}$, Muhammad Saleem $^{2}$, Ali Aziz $^{2}$, \\ Irfan Rasool' ${ }^{2}$ Zeshan $\mathrm{Ali}^{3}$ and Muhammad Amin ${ }^{2}$
}

${ }^{1}$ Gram Breeding Research Station, Kallurkot, Pakistan; ${ }^{2}$ Pulses Research Institute, AARI, Faisalabad Pakistan; ${ }^{3}$ Plant Physiology Program, Crop Sciences Institute, National Agricultural Research Centre, Park Road, Islamabad PO 45500, Pakistan.

\begin{abstract}
Helicoverpa armigera is considered as widespread and cosmopolitan insect responsible for drastic decline in chickpea productivity across the world. Management of $H$. armigera is of prime importance to achieve sustainable chickpea yields. Its life cycle passes through egg, larvae, pupae and adult stages in about 4-5 weeks. $1^{\text {st }}$ to $3^{\text {rd }}$ instar larvae generally feed on leaves, twigs and flowers. In later stages larger larvae $\left(4^{\text {th }}\right.$ to $6^{\text {th }}$ instar caterpillars) shift to developing pods by making holes/bores and consume entire developing seeds. Pod borers can cause yield losses up to 90 percent depending upon the insect density and susceptibility of cultivars. Sustainable management of chickpea pod borer involves use of resistant cultivars, manipulation of sowing dates, maintaining low crop density, management of nutrition, use of trap crops (maize, sunflower, sorghum, safflower, pigeon pea, okra and tomato), installing animated bird perches and application of biological control measures (use of plant extracts, virus/bacteria based insecticides). In case of pod borer outbreaks, chemical insecticides remain as last option for farmers. However, management of chickpea pod borer through use of resistant cultivars, adopting recommended cultural practices and biological control measures have been found more effective, economical, sustainable and eco-friendly.

Received | September 26, 2020; Accepted | November 17, 2020; Published | February 23, 2021

*Correspondence | Muhammad Tariq Mahmood, Gram Breeding Research Station, Kallurkot, Pakistan; Email: taqaisrani@gmail.com

Citation | Mahmood, M.T., M. Akhtar, M. Ahmad, M. Saleem, A. Aziz, I. Rasool, Z. Ali and M. Amin. 2021. An update on biology, extent of damage and effective management strategies of chickpea pod borer (Helicoverpa armigera). Pakistan Journal of Agricultural Research, 34(1): 91-101. DOI | http://dx.doi.org/10.17582/journal.pjar/2021/34.1.91.101

Keywords $\mid$ H. armigera, Chickpea, Management, Pod damage
\end{abstract}

\section{Introduction}

$\mathrm{C}$ hickpea (Cicer arientinum L.) is exposed to a wide range of insect pests, of which pod borer [Helicoverpa armigera (Hubner)] is most common and critical challenge for chickpea productivity around the world (Luckmann and Metcalf, 1975; Ujjan et al., 2019; Jai et al., 2020). In case of outbreaks, yield losses caused by chickpea pod borer range from 1090 percent depending upon the insect population and susceptibility of genotypes (Sharma et al., 2012). $H$. armigera is widely dispersed throughout the African, Asian, European and Mediterranean regions (Anwar and Shafiq, 1993; EPPO, 2006; Fichetti et al., 2009; Zohary et al., 2012). In Europe H. armigera is widespread chickpea pest while limited distribution of pest has been reported in Hungry, France, Italy and Cyprus (Patil et al., 2017). Former reports on extent of damage by pod borer are evident that significant yield losses have been recorded in Southern Asia. Pod damage in unprotected chickpea crops were recorded up to $90 \%$ in Pakistan (Ahmed et al., 1986), in India up to $85 \%$ (Reed, 1983) and 5-15\% in Bangladesh (Pande and Rao, 2000).

$H$. armigera belongs to insect order Lepidoptera, 
family Noctuidae. Its life cycle involves four major developmental stages (eggs, larvae, pupae and adult). $H$. armigera completes its life cycle from egg to adult in about 30-34 days at an average temperature of $28{ }^{\circ} \mathrm{C}$ (Zalucki et al., 1986; Fichetti et al., 2009). Under favorable environmental conditions adult insect (Moth) lay eggs which goes through various developmental stages i.e egg changes into $\mathrm{I}^{\text {st }}$ to $6^{\text {th }}$ instars caterpillar (larvae) which afterward change into pupa and then adult moth is developed. It $^{\text {st }}$ to $3^{\text {rd }}$ instar larvae generally feed on twigs, leaves and flowers. In later stages larger larvae move to developing pods by making holes/bores and consume entire developing seeds resulting in severe yield losses (Reed and Pawar, 1982).

Pod borer can survive on several host species of crop plants. Pawar et al. (1986) reported 182 host species of crop plants for $H$. armigera. 47 species of host plants were reported by Singh and Balan (1986). They also added that gram, tomato and Egyptian clover were most favorable for larval survival. Naresh et al. (1989) reported maize, chickpea, sorghum, pigeon pea, okra, tomato and several other crops as preferred host crops for survival of $H$. armigera. Out breaks of pod borer have been observed on chickpea crop due to cultivation of cotton, pigeon pea, maize, tomato, sorghum, cowpeas and okra crops in surroundings because of shift of pest populations to chickpea crop (Reed, 1983; Patil et al., 2017). Rotation of common host crops has contributed to lift up the polyphagous insect pest populations like chickpea pod borer (Rivnay, 1962). Irrigation strategies generate new habitats promoting the migration process of some species of pests to the areas that were otherwise away from reach and the insect populations generally develop and migrate to that area (Bhatnagar, 1987).

Management of $H$. armigera is of prime importance to achieve sustainable chickpea yields. Integrated pest management strategies have been emphasized by several researchers to minimize the pest populations which include use of resistant cultivars, adoption of recommended cultural practices and use of biological and chemical control measures (Navi et al., 2018; Ujjan et al., 2019). Uses of pod borer resistant cultivars guarantee a pest free crop and incur almost no further charge to chickpea growers (Rajesh et al., 2017). Similarly, early sowing of chickpea crop, optimum plant density, installing insectivorous bird perches and intercropping with trap crops is also helpful in pest management. Several natural pathogens, insect parasitoids, predators and plant materials are being extensively utilized for biological management of pod borer (Bhatnagar, 1987). In case of insect outbreaks, insecticides remain as last option for farmers. Several insecticide groups (pyrethroids, hydrocarbons, carbamates, organophosphates) have been introduced for chemical control of pod borer (Schulten, 1987).

\section{Life cycle of helicoverpa armigera}

Helicoverpa armigera completes its life cycle (from egg to adult) in 4-5 weeks at an average temperature of $28{ }^{\circ} \mathrm{C}$ (Zalucki et al., 1986; Patil et al., 2017; Jai et al., 2020). Egg, larva, pupa and adult are four major stages of its life cycle (Figure 1). Adult insects having stout bodies with broad thorax are named as Moth. A female moth can lay up to 3000 eggs. Eggs are generally laid on leaves, pods and flowers. Oviposition period may last for 5-24 days and egg incubation occurs in 3-5 days depending upon temperature and host plant. Color of freshly laid eggs is yellowish-white that change into shady brown prior to hatching (Ali et al. 2009). After hatching larvae are released having six distinct instars (1-6 instars caterpillar). Initially larvae feed on leaves, younger twigs and flowers but in later stages they enter into the developing pods by making holes from the pod basis (Singh and singh, 2007). Pre-pupa period lasts for 1-4 days. Generally, the pupal period ranges from 10-16 days however it depends on temperature by taking 6 days at $35^{\circ} \mathrm{C}$ and up to 30 days on $15^{\circ} \mathrm{C}$. Under very low temperature (in winter) and very high temperature (in summer) it exhibits a facultative diapause to stay alive under unfavorable environmental conditions. Pupae exposed to exceeding $30^{\circ} \mathrm{C}$ temperatures produce pale colored adults (Patil et al., 2017). Male and female adults have distinguished color pattern showing greenishgrey and orange brown respectively. Pearson (1958) reported that female moths generally live longer than male.

\section{Management approaches for chickpea pod borer}

Sustainable management approaches for chickpea pod borer include varietal resistance, adoption of recommended cultural practices, and use of biological and integrated pest management measures.

\section{Varietal resistance}

Several characteristics antixenosis, pod thickness, length,density and pods plant ${ }^{-1}$ significantly contribute towards resistance against chickpea pod borer (Ujagir 
and Khere, 1987; Rajesh et al., 2017). Trichome types, length, density and orientation are associated with reduced pod damage. The association among pod borer damage and pod wall thickness exhibit negative correlation therefore genotypes having more wall thickness are generally less damaged. Similarly, pod length, area and breadth have also a considerable effect on pod borer resistance showing a negative association among the extent of damage, pod length and area. However, positive associations among pod borer damage and the pods plant ${ }^{-1}$ have been reported (Jeffree, 1986; Peter et al., 1995).

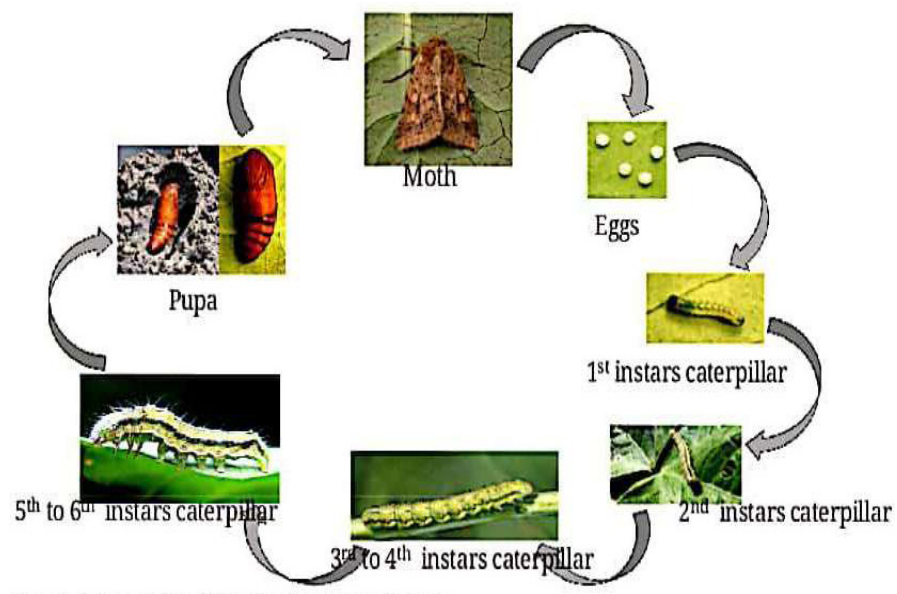

Figure 1: Life cycle of Helicoverpa armigera.

Development and utilization of pod borer resistant cultivars serves as the most efficient and sustainable control method for chickpea pod borer. Utilization of resistant varieties is most effective method and incurs no extra charge to the growers. Hence, the breeding objective must be to identify and utilize the genetic resistance sources to chickpea pod borer. Development of genetically advanced varieties having improved pod borer resistance is feasible provided that a good source of resistance is available. The selection procedures like mass selection, bulk and pedigree selection approaches can be utilized for the development of chickpea pod borer resistant varieties. Recurrent selection procedure has been found more efficient to accumulate the desired alleles in a single genotype and to break the undesired blocks (Singh et al., 1991; Sharma, 2005). These schemes require characterization of large populations, repeated selections and inter crossing among selected parents. Mutation breeding can also be utilized for creation genetic variation in performance of various traits having positive influence on resistance for pod borer damage. Singh et al., 1991 reported that the parents ICC 10619, ICCL 84205 and ICC 506 with low borer damage were found resistant to pod borer damage.

Lateef, 1985 and Sharma, 2005 found several accessions of germplasm (ICC-10817, ICCV -95992, ICC-10243, ICC-10667, ICC-10619, ICC-4935 and ICC-506EB resistant to chickpea pod borer while the genotypes like ICCL-86103, ICCV-10, ICCV-7 were found moderately resistant to chickpea pod borer. Several studies on genetic resistance and use of molecular markers were conducted by different researchers to identify the tolerant and resistant sources. The tolerant/ resistant sources against pod borer have been given in the (Table 1 ).

\section{Cultural practices}

Sowing time: Chickpea productivity is greatly influenced by the sowing time of crop. Environmental factors, like humidity, temperature, sunshine hours, and wind speed affect the pod borer populations. Kumar and Bisht, 2013, reported that temperature is positively correlated with the pod borer larval population, whereas rainfall and relative humidity reduce the larval population. Late sown crop is generally more affected by pod borer than early sown crop (Akhtar et al., 2014). Singh et al., 2002 concluded that in delayed sowing less grain yield indicated the direct correlation of yield to pod damage. Parmar et al. (2015) recorded low pod borer larval population and less pod damage percentage in early sown crop.

Generally, crop sown during October suffers least in comparison to late sown crop under Pakistan and Indian condition (Patil et al., 2017). The early instars generally appear in early April which remain restricted on leaves for food. However, the later instars, responsible for considerable pod damage, usually appear in late April. At that time, the pods are fully developed and mature enough that a limited damage can take place. Consequently, the early-sown chickpea crop escapes this period.

Plant density: Plant density and planting geometry also affects the extent of pod damage. Qadeer and Singh, 1989, reported that a denser chickpea crop favors enhanced pod damage. Anil et al., 2011 concluded that denser crops generally harbored higher larval population resulting in yield loss. Thinning may be recommended to reduce the plant density, because in some cases chickpea growers have a limited opportunity to minimize seed rate due to adverse physical soil conditions and unreliable seed germination. 
Table 1: Resistant sources to chickpea pod borer (H. armigera).

\begin{tabular}{|c|c|c|}
\hline Country & Tolerant genotypes & References \\
\hline \multirow[t]{9}{*}{ Pakistan } & $\mathrm{Pb}-91$ & Shahzad et al., 2005 \\
\hline & $\mathrm{C}-27$ & Sarwar et al., 2009 \\
\hline & CM-72 & Khan et al., 2009 \\
\hline & $\mathrm{CH}$ 07/02, CH 20/02, CH 84/02 and CM 188/01 & Shafique et al., 2009 \\
\hline & $\mathrm{CH} 4 / 02, \mathrm{CH} 9 / 02, \mathrm{~B} 8 / 02$ and $\mathrm{B} 8 / 03$ & Nadeem et al., 2010 \\
\hline & $\mathrm{CH} 73 / 02$ & Nadeem et al., 2011 \\
\hline & $\mathrm{CH}-53 / 99, \mathrm{CC}-94 / 99, \mathrm{CM}-24-2 / 02$ and CM-210/01 & Sarwar, 2013 \\
\hline & K-70005 & Shabbir et al., 2014 \\
\hline & NIFA-2005, DG-89 and DG-92 & Hafeez et al., 2018 \\
\hline Myanmar & ICC-506 and ICCX-730008 & Ahmed et al.,1990 \\
\hline Nepal & $\begin{array}{l}\text { GLK-88341, ICCV-88102, ICCX-860043-BP, ICCX-900239-BP and } \\
\text { ICCV-95991 }\end{array}$ & Thakur, 1998 \\
\hline \multirow[t]{11}{*}{ India } & Chaffa & Bhatt and Patel, 2001 \\
\hline & $\mathrm{C}-727$ & Rajput et al., 2003 \\
\hline & ICCV-2, ICC-87311 & Sanap and Jamadagni, 2005 \\
\hline & ICCV-7, JG-74, ,JG-130,JG-315 and BG-256 & Ahmad and Rai, 2005 \\
\hline & IPC 96-3 & Kaur et al., 2005 \\
\hline & ICC-16374 & Patil et al., 2007 \\
\hline & ICC-12478, ICC-12479 and ICC-506 EB & Lakshmi Narayanamma et al., 2007 \\
\hline & Avrodhi , Vijay, BG-372, HC-1 and SAKI-9516 & Deshmukh et al., 2010 \\
\hline & Vishal , Vijay, ICPL 88034 and ICCV 10 & Sharma et al., 2014 \\
\hline & CSJD-884 and RSG-931 & Choudhary et al.,2015 \\
\hline & BG-256 and KPG-59 & Rajesh et al., 2017 \\
\hline Bangladesh & $\begin{array}{l}\text { BCX-91042-3, BCX-91040-3, ICCV-95138, ICCV-98939, ICCV- } \\
96020 \text { and ICCV-97004 }\end{array}$ & Hossain (2009) \\
\hline \multirow[t]{2}{*}{ Kenya } & $\begin{array}{l}\text { ICC-3362, ICC-2580, ICC-7272, ICCV-92311, ICCV-95311, ICC 506, } \\
\text { ICCVX 906183-1 and EC-583311 }\end{array}$ & , Mulwa et al. (2010) \\
\hline & EC583250, EC583264, EC58318, EC583260 ICC14831 and ICCV10 & Ruttoh et al. (2013) \\
\hline Sudan & Flip03-139c and Atmore & Mansour and Mohamed, 2014 \\
\hline
\end{tabular}

Nutrient management: Coaker (1987) narrated that application of nutrients to crop exhibit direct effect on pest attacks. Increased application of NPK enhances the plant growth which and crop becomes more attractive to chickpea pod borer. Hossain et al. (2009) concluded that the bushy plant types provide better refuge for insects, resulting in more pod damage while low doses of NPK resulted in less pod damage. Similarly, Anilkumar et al. (2011) reported that increased phosphorous levels significantly minimized insect incidence and increased the chickpea seed production. Fertilizer applications change the plant physiology and makes it active host for pod borer (Coaker, 1987). Application of inorganic fertilizers to chickpea crop showed higher pest population in comparison to the organic manures (Singh and Singh, 2007). Ramakrishnan et al.
(1983) also studied the fertilizer effect on pod borer population and cited that nitrogenous fertilizers have direct effect on pod damage. Therefore, reduced NPK doses may be recommended to control the pod borer population.

Use of trap crops: The crops cultivated to lure insect pests away from the commercial crops are generally known as trap crop. Insects are either prohibited to enter the crop or trapped in other crops away from the major crop. Method of trap cropping depends on pest species as well as on stage of crop. Certain plants produce chemicals that catch the attention of insects for pollination, which make them fit trap crop. Various species of crop plants produce different degrees of volatiles, permitting certain species of insects and have been found suitable for trap cropping (Naresh et 
al., 1989; Sarwar et al., 2009).

When insect population is concentrated in a trap crop, they may be easily managed by applying recommended treatments techniques in specific area instead of treating the whole crop. Such treatments are less expensive and most effective to control insect populations. The crops like maize, sunflower, sorghum, safflower, pigeon pea, okra and tomato have been found as host crops and may be exploited as trap crops on borders or repeated in rows with a ratio of 10:3 (Chickpea: Trap crop rows respectively) across the field. A study involving sunflower and marigold as trap crops with a ratio of 7:1 resulted in $34-40 \%$ reduced pod damage (Anonymous, 2009).

Intercropping or mixed cropping: Intercropping with several other crops provides insurance in the farming ecosystem against the insect pest. Intercropping of common host crops has also contributed to lift up the populations of polyphagous insect pests like $H$. armigera therefore intercropping of non host crops resulted in reduced larval populations (Rivnay, 1962). Intercropping manipulates the crop geometry and the cropping system and inhibits the larval population of insects to migrate from a certain location of crop to another. Pimbert (1990) reported that intercropping of chickpea with certain crops do not offer same kind of stimuli and companionship for the pod borer therefore less extent of damages were revealed.

Ahmad (2003) concluded that chickpea intercropped with mustard, wheat, linseed and non host crops revealed considerably less pod injury in comparison to the sole chickpea crop. Similarly, $38.3 \%$ less pod borer damage was recorded by Ali et al. (2009) in wheat + chickpea mixed cropping than chickpea solitary cropping. Intercropping effect of chickpea + linseed was investigated by Borah et al. (2010) who found reduced incidence along with delayed pod borer attack. Tripathi et al. (2008) studied chickpea + mustard intercropping and narrated highest chickpea grain yield and reduced larval population followed by chickpea + barley intercropping. Similarly studies on intercropping of chickpea with coriander, sunflower and safflower also resulted in low yield loss and reduced pod damage (Pattar et al., 2012).

\section{Biological control}

Biological control agents serve as more efficient alternative of chemical, eco-friendly, sustainable and economical. These agents provide reliable control of chickpea pod borer incurring no extra cost to farmers. Sources of such agents are generally living organisms and their products or by products. Biological managements often rely on parasitism, herbivory, and predation or other natural mechanisms.

Plants and animal based extracts have been found safer, benign and cost effective in comparison to the chemical insecticides (Kamanula et al., 2011; Jai et al., 2020). Azadirachtin is a common plant extract isolated from neem plant. Roy and Dureja (1998) cited that Azadirachtin has growth-retarding and can cause death of insects by interfering the neuroendocrine control during metamorphosis. Zhu et al. (2001) reported that mixture of neem and garlic extract has repellent, toxic and anti oviposition effect on insects. Mishra et al. (2013) cited that vitex leaf extract, vermiwash, neem oil, pongamia leaf extract and animal urine have insect repellent properties and reported significant reduction in pod damage. Application of neem seed extracts was investigated by Hussain et al., 2016 who also found notable decline in pod borer population.

Virus and bacteria based insecticides have also been found most efficient in controlling pod borer outbreaks. Jai et al. (2020) reported that species specific nuclear polyhedrosis viruses (NPVs) have significant degrees of infestation to chickpea pod borer. Sharma et al. (1997) investigated NPV and a chemical insecticide Endosulfan in and found that NPV reduced pod damage up to $78 \%$ while $70 \%$ with Endosulfan. Bacteria based insecticide also provide an eco-friendly and effective control against chickpea pod borer. Chemical insecticides have hazardous and toxic effects on soil, environment, mammals and birds while the microbial insecticides have no residual effects and are considered as eco-friendly alternatives (Ahmed et al., 2012). Bacteria based (Bt) insecticides have been found more effective IPM tool for the pod borer. Utilization of $\mathrm{Bt}$-based insecticides with DiPel, Delfin, BioBit in combination with NPV found most efficient with reduced pod damage (Hussain et al., 2016).

Numerous species of predatory birds feed on several insects, which may reduce the insect population up to $84 \%$ (Chakravarthy, 1988). Among these insectivorous birds, house sparrows, black drogue, rosy pastor, blue jays, mynah and cattle egret and 
are common predators which feed on several insect pests including chickpea pod borer (Gokhale and Ameta, 1991). The sunflower provides sitting place for the predatory birds and its intercropping in chickpea reduces the larval population within a short time. Gopali et al. (2009) studied the sowing of sunflower and sorghum intercropped with chickpea crop and recorded higher chickpea grain yield when intercropped with sunflower due to bird perches. Ali and Dillon (1983) narrated that the beneficial role of insectivorous birds is the rich heritage of the nature in plant protection scenario. Bird perches are ecofriendly measure to control the insect populations rather than using the chemical insecticides.

\section{Chemical control}

In case of pod borer outbreaks, insecticides remain as last option for farmers. Several researchers have investigated the efficacy of certain insecticides and made recommendation of different insecticides for effective management of chickpea pod borer. Rashid et al. (2003) investigated the effect of insecticides i.e. Chlorpyrifos, Endosulfan, Indoxicarb, profenofos and spinosad along with untreated check against gram pod borer ( $H$. armigera) and concluded that Indoxicarb and spinosad were found most effective with significant reduction of pod borer in chickpea crop. Ahmed et al. (2004) studied efficacy of various insecticides to chickpea pod borer and reported that spinosad was found most useful for management of chickpea pod borer followed by indoxacarb.

Similarly, the insecticides; cyperthrine $10 \%$ EC, deltamethrine 2.8\% EC, emamectin benzoate $5 \%$ $\mathrm{SC}$, endosulfan $35 \% \mathrm{EC}$, flubendiamide $480 \% \mathrm{EC}$, fenvalenrate $20 \% \mathrm{EC}$, indoxicarb $15 \% \mathrm{EC}$, lambda cyhalothrine $5 \% \mathrm{EC}$, quinalphos $25 \% \mathrm{EC}$, thiacloprid $240 \% \mathrm{SC}$ and spinosad $45 \%$ have also been found effective for control of $H$. armigera in various former research studies (Narayana and Rajasri, 2006; Gowda et al., 2007).

\section{Conclusions and Recommendations}

Chickpea pod borer can be effectively managed by integration of measures such as use of resistant varieties, adaptation of recommended cultural practices and use of biological and chemical insecticides. Less plant density and intercropping with trap crops (mustard, coriander, marigold, sunflower, sorghum and linseed) and installing animated bird perches also help to attain enhanced chickpea productivity. However, in case of insect outbreaks generally chemical insecticides remain as the only solution. Due to harmful residual effects of pesticides for the food chain, soil and the natural balance, application of chemicals should be avoided. Sustainable management of pod borer can't be attained by applying any single measure therefore an integrated management approach following all the recommendations/ principles required to safeguard the crop is necessary. In view of this, it can be concluded that integration of all measures must be practiced to manage chickpea pod borer and to attain sustainable crop productivity.

\section{Novelty Statement}

This review covers salient former research outcomes and includes most recent accomplishments pertaining to the biology and efficient management of chickpea pod borer (Helicoverpa armigera). This novel review will help researchers and chickpea growers to potentially enhance chickpea yield in affected agroecologies.

\section{Author's Contributions}

MTM, MA, MS and IR studied former research findings and collected necessary information. MTM wrote the article. IR, MA, ZA remained involved in review and necessary revisions.

\section{Conflict of Interest}

The authors have no conflict of interest.

\section{References}

Ahmed, K., F. Khalique, M. Afzal and B.A. Malik. 1986. Pulses entomology report. Food legumes improvement programme. Pakistan Agricultural Research Council, National Agricultural Research Center, pp. 4-10.

Ahmed, K., S.S. Lal, H. Morris, F. Khalique and B.A. Malik. 1990. Insect-pest problems and recent approaches to solving them on chickpea in South Asia. In: Proceeding of second international workshop on chickpea improvement, 4-8 December 1989, ICRISAT, Patancheru, India, pp. 165-168.

Ahmed, K., F. Khalique, S.A. Durrani and K.D. Pitafi. 2012. Field evaluation of bio-pesticide for control of chickpea pod borer Helicoverpa 
armigera, a major pest of chickpea crop. Pakistan J. Zool., 44(6): 1555-1560

Ahmad, R., 2003. Insect pests of chickpea and their management. In: M. Ali, S. Kumar and N.B. Singh (eds.) Chickpea research in India. Indian Institute of Pulses Research, Kanpur, pp. 69-72.

Ahmad, R. and A.B. Rai. 2005. In: Shiv-Kumar, Singh, M. (eds.) 25 years of research on Helicoverpa at IIPR. Indian Institute of Pulses Research, Kanpur, pp. 54.

Ahmed, S., K. Zia and N. Shah. 2004. Validation of chemical control of gram pod borer, Helicoverpa armigera (Hubner) with new insecticides. Int. J. Agric. Biol. Pak., 6(6): 978-980.

Akhtar, M.F., I. Ahmed, I. Nadeem, Q. Abbas, A. Raza, M.J. Yousaf, R. Ahmed and T. Niaz. 2014. Impact of different dates of sowing on gram pod borer (Helicoverpa armigera) infestation in chickpea crop. World J. Zool., 9(4): 270-275.

Ali, A., R.A. Choudhury, Z. Ahmad, F. Rahman, F.R. Khan and S.K. Ahmad. 2009. Some biological characteristics of Helicoverpa armigera on chickpea. Tunn J. Plant Prot., 4: 99-106.

Ali, S. and R.S. Dillon. 1983. A pictorial guide to the birds of the Indian Subcontinent. Bombay Natural History, Oxford, pp. 176-188.

Anilkumar, R., B. Nandan, J.P. Sharma and J. Kumar. 2011. Effect of phosphorus and seed rate on growth and productivity of bold seeded Kabuli chickpea in subtropical Kandi areas of Jammu and Kashmir. Plant Arch., 10(1): 125129.

Anwar, M. and M. Shafique. 1993. Integrated control of gram pod borer, Helicoverpa armigera (Hubner) in Sindh. In: Proceedings of Pakistan Congress of Zoology. pp. 215-222.

Anonymous, 2009. Annual report 2008-09, All India Coordinated Research Project on Chickpea (AICRPC), Directorate of Pulse Research, Kanpur, India. pp. 90-99.

Bhatnagar, V.S., 1987. Conservation and encouragement of natural enemies of insect pests in dryland subsistence farming: Problems, progress and prospects in the Sahelian Zone. Insect. Sci. Appl., 8: 791-795. https://doi. org/10.1017/S1742758400022931

Bhatt, N.J. and R.K. Patel. 2001. Screening of chickpea cultivars for their resistance to gram pod borer Helicoverpa armigera (Hb). Indian J. Ent., 63: 277-280.
Borah, B.K., M.C. Debnath, K.K. Sharma and B. Das. 2010. Effect of intercropping on incidence of gram pod borer, Helicoverpa armigera Hubner in chickpea. Insect Environ., 15(4): 8-9.

Chakravarthy, A.K., 1988. Bird predators of pod borers of field bean (Lablab niger). Trop. Pest. Manage., 34: 395-398. https://doi. org/10.1080/09670878809371285

Coaker, T.H., 1987. Cultural methods. In: Burn, A.J., Coaker, T.H. and Jepson, P.C. (eds.) The crop in integrated pest management. Academic Press, London, pp. 69-88

Choudhary, O.M., R. Anwala and M.M. Sharma. 2015. Studies on varietal screening and date of sowing of chickpea [Cicer arietinum (L.)] against Helicoverpa armigera (Hub.). J. Ecofriendly Agric., 10(1): 58-61.

Cunningham, J.P., M.P. Zalucki and S.A. West. 1999. Learning in Helicoverpa armigera (Lepidoptera: Noctuidae): A new look at the behavior and control of a polyphagous pest. Bull. Entomol. Res., 89: 201-207. https://doi. org/10.1017/S0007485399000310

David, H. and Easwaramoorthy, 1988. Physical resistance mechanisms in insect plant interactions. In: Ananthakrishnan, T.N. and Raman, A. (eds.) Dynamics of insect plant in and future trends. Oxford and IBH Publication, New Delhi, pp. 45-70.

Deshmukh, S.G., B.V. Sureja, D.M. Jethva, V.R. Sonune and D.M. Joshi. 2010. Field screening of chickpea germplasms against pod borer, $\mathrm{H}$. armigera. Legume Res., 33(2): 150-151.

EPPO, 2006. Distribution maps of quarantine pests, Helicoverpa armigera. On-line available at www.eppo.org/QUARANTINE/insects/ Helicoverpa_armigera/HELIAR_map.html

Fichetti, P., S. Avalos, V. Mazzuferi and C. Carreras. 2009. Lepidópteros asociados al cultivode garbanzo (Cicer arietinum L.) en Córdoba, Argentina. Bol. Sanid Veget Plagas. 35: 49-58.

Gokhale, V.G. and O.P. Ameta. 1991. Predatory behavious of house sparrow, Passer domesticus L. in the population regulation of Heliothis sp. infesting chickpea, Cicer arietinum. Indian J. Ent., 53: 631-634.

Gopali, J.B., R. Teggelli, D.M. Mannur and S. Yelshetty. 2009. Bird perches for sustainable management of pod borer, Helicoverpa armigera (Hubner) in chickpea ecosystem. Karnataka J. 
Agric. Sci., 22(3-Spl. Issue): 541-543.

Gowda, D.K.S., B.V. Patil and S. Yelshetty. 2007. Performance of different sprayers against gram pod borer, Helicoverpaarmigera (Hubner) on chickpea. Karnataka J. Agric. Sci., 20(2): 261264.

Jamro, H.U.R., M.I. Khaskheli, J.M. Mari and M.A. Rustamani. 2018. Screening of available chickpea genotypes for resistance potential against gram pod borer, helicoverpa armigera (hubner) in Sindh, Pakistan. Int. J. Dev. Res., 8(7): 21656-21662.

Hossain, M.A., M.A. Haque and M.Z.H. Prodhana. 2008. Effect of pods char-acteristics on pod borer, Helicoverpa armigera (Hubner), investigation in chickpea. SAARC J. Agric., 6(1): 1-11.

Hossain, M.A., M.Z.H.Prodhan and M.A. Haque. 2009. Response of NPK fertilizer on incidence of pod borer, Helicoverpa armigera (Hubner) and grain yield of chickpea. Bangladesh $\mathrm{J}$. Sci. Ind. Res., 44(1): 117-124. https://doi. org/10.3329/bjsir.v44i1.2720

Hussain, M., K.S. Ahmad, M. Majeed, A. Mehmood, A. Hamid, M.M. Yousaf, M.S. Chaudhry, M.J. Shah, K. Hussain, B. Ahmad and A.Q. Khan. 2016. Integrated management of Helicoverpa armigera on different genotypes of Kabuli chickpea in Punjab, Pakistan. Int. J. Biosci., 9(2): 110-119.

Jai, B.K., V.K. Soni and H.K. Chandraker. 2020. Surveillance of pod borer, Helicoverpa armigera (Hubner) and its natural enemies on chickpea at Sahaspur Lohara blocks. J. Pharm. Phytochem., 9(3): 1995-2000.

Jeffree, E., 1986. The cuticle, epicuticular waxes and trichomes of plants, with reference to their structure, functions and evolution. In: B.E. Juniper and T.R.E. South surface. Edward Arnold Publication Ltd., London. pp. 23-64.

Kamanula, J., G.W. Sileshi, S.R. Belmain, P. Sola, B.M. Mvumi, G.K.C. Nyirenda, S.P.N. Nyirenda and P.C. Stevenson. 2011. Farmers' insect-pest management practices and pesticidal plant use for protection of stored maize and beans in Southern Africa. Int. J. Pest. Manage., 57(1): 41-49. https://doi.org/10.1080/0967087 4.2010 .522264

Kaur, H., S.K. Gupta, D. Singh and K. Singh. 2005. Preliminary evaluation of chickpea genotypes for resistance to pod borer and wilt complex.
Int. Chickpea Pigeon Pea Newsl., 12: 39-40.

Kumar, L. and R.S. Bisht. 2013. Population dynamics of Helicoverpa armigera (Hubner) on chickpea crop. Pantnagar J. Res., 11: 35-38.

Lal, O.P, 1996. An outbreak of pod borer, Heliothis armigera (Hubner) on chickpea in eastern Uttar Pradesh. Indian J. Entmol. Res., 20: 179-181.

Narayana, L.S. and M. Rajasri. 2006. Flubendiamide 20 WDG (RIL-038) a new molecule for the management of American bollworm, Helicoverpa armigera (Hubner) on cotton. Pestology, 15(11): 16-18.

Narayanamma, L.V., M. Sriramulu, C.L.L. Gowda, M.A. Ghaffer and H.C. Sharma. 2007. Tolerance to Helicoverpa armigera damage in chickpea genotypes under natural infestation. Indian J. P1. Prot., 35(2): 227-231.

Lateef, S.S., 1985. Gram pod borer (Heliothis armigera) (Hub.) resistance in chickpea. Agric. Ecosyst. Environ. 14: 95-102. https://doi. org/10.1016/0167-8809(85)90087-8

Lateef, S.S. and M.P. Pimbert. 1990. The search for host-plant resistance to Helicoverpa armigera in chickpea and pigeonpea at ICRISAT. Summary Proc. of the first consultative group meeting, 5-7 March 1990, ICRISATCenter, India. pp. 14-18.

Luckmann, W.H. and L. Metcalf. 1975. Introduction to insect-pest management. Wiley, New York, pp. 3-35.

Mansour, A.E.A. and A.A. Mohamed. 2014. Evaluation of different chickpea genotypes for resistance against pod borer, Helicoverpa armigera (Hub.) (Lepdoptera: Noctuidae) under field conditions, Sudan. Int. J. Agric. Innov. Res., 2(6): 1147-1149.

Mishra, K., K. Singh and C.P.M. Tripathi. 2013. Management of pod borer (Helicoverpa armigera) infestation and productivity enhancement of gram crop (Cicer aritenium) through vermiwash with biopesticides. World J. Agric. Sci., 9(5): 401-408.

Mulwa, R.M.S., P.K. Kimurto and B.K. Towett. 2010. Evaluation and selection of drought and pod borer (Helicoverpa armigera) tolerant chickpea genotypes for introduction in semiarid areas of Kenya. In: Second RUFORUM biennial meeting, pp. 20-24.

Nadeem, S., M. Hamed, M. Shafique, B.M. Atta and T.M. Shah. 2011. Evaluation for resistance in Kabuli chickpea genotypes against 
chickpea pod borer, Helicoverpa armigera (Hübner) (Lepidoptera: Noctuidae) under field conditions. Songklanakarin J. Sci. Technol., 33(3): 291-294.

Nadeem, S., M. Shafique, M. Hamed, B.M. Atta and T.M. Shah. 2010. Evaluation of advanced chickpea genotypes for resistance to pod borer, Helicoverpa armigera (Hübner) (Lepidoptera: Noctuidae). Pak. J. Agric. Sci., 47(2): 132-135.

Naresh, J.S., V.S. Malik and S.K. Kaushik. 1989. Larval population and damage of Heliothis armigera (Hubn.) estimated on different plant densities of chickpea during five weeks. Bull. Ent., 27: 70-73.

Navi, S., S.C. Kumar, N.T. Naresh, G.S. Yogesh and C. Hanagi. 2018. Evaluation of IPM Package against pod borer, Helicoverpa armigera (Hubner) in chickpea through front line demonstration in Chamarajanagar district of Karnataka. Int. J. Chem. Stud., 6: 843-845.

Pande, S. and J.N. Rao. 2000. Integrated management of chickpea in the rice based cropping systems of Nepal: Progress report of the ICRISAT and NARC (Nepal Agricultural Research Council, Khumaltar) collaborative work in farmers participatory on farm trials on the validation of improved production practices [specifically integrated pest (diseases and insects) management (IPM)] in seven villages of five districts in Nepal, 29 ${ }^{\text {th }}$ October 1999 to 30th April 2000. International Crops Research Institute for the Semi-Arid Tropics (ICRISAT), Patancheru, Andhra Pradesh, India, pp. 33.

Parmar, S.K., A.S. Thakur and R.S. Marabi. 2015. Effect of sowing dates and weather parameters on the incidence of Helicoverpa armigera (Hubner) in chickpea. Bioscan, 10(1): 93-96.

Patil, S.B., A. Goyal, S.S. Chitgupekar, S. Kumar and M. El-Bouhssini. 2017. Sustainable management of chickpea pod borer. A review. Agron. Sustain. Dev., 37: 20. https://doi. org/10.1007/s13593-017-0428-8

Patil, S.K., G.P. Shinde and B.M. Jamadagni. 2007. Reaction of short-duration chickpea genotypes for resistance to gram pod borer Helicoverpa armigera in Maharashtra, India. SAT J., 5(1): 1-2.

Pattar, P.S., C.P. Mansur, S.C. Alagundagi and S.S. Karbantanal. 2012. Effect of intercropping systems on gram pod borer Helicoverpa armigera Hubner and its natural enemies in chickpea. Indian J. Ent., 74(2): 136-141.

Pawar, C.S., V.S. Bhatnagar and D.R. Yadhav. 1986. Heliothis spp. and their natural enemies with their potential for biological control, Proc. Indian Acad. Sci. Anim. Sci., 95: 697-703. https://doi.org/10.1007/BF03179484

Pearson, E.O., 1958. Insect pests of cotton in tropical Africa. Commonw. Inst. Entomol., Lond., pp. 355.

Peter, A.J., T.G. Shanower and J. Romeis. 1995. The role of plant trichomes in insect resistance: $A$ selective review. Phytophaga, 7: 41-64.

Pimbert, M.P., 1990. Some future research directions for Integrated Pest Management in chickpea: a viewpoint. Chickpea in the nineties. In: Proceeding of Second International Workshop on Chickpea Improvement, 4-8 December 1989, ICRISAT, Patancheru, India, pp. 151-163.

Qadeer, G.A. and Y.P. Singh. 1989. Some observations on outbreak of gram pod borer on grain during rabi 1987-88 in Haryana. P1. Prot. Bull., 41(1-2): 24-25.

Rahman, A., M.Q. Saeed, J. Noora and M. Ahmad. 2006. Efficacy of some new insecticides againstgram pod borer Helicoverpa armigera (Hub.) in Peshawar. Sarhad J. Agric. 22(2): 293-295.

Rajesh, K., M.K. Chakravarty, P. Mondal and S. Chakraborty. 2017. Evaluation of advanced chickpea genotypes for resistance to pod borer, Helicoverpa armigera (Hübner). Int. J. Curr. Res., 9(1): 44580-4458.

Rajput, A.A., M. Sarwar, N. Ahmad, Q.H. Siddiqui and M. Toufiq. 2003. Evaluation for resistance in some local and exotic chickpea geno-types against Helicoverpa armigera (Hubner). Pak. J. Biol. Sci., 6: 1612-1615. https://doi. org/10.3923/pjbs.2003.1612.1615

Ramakrishnan, C., T. Radhakrishnan, D.G. Rama. 1983. Effect of nitro-gen, rhizobium inoculation and phosphorus level on damage of pi-geon pea by H. armigera. Int. Pigeon Pea Newsl., 2: 62.

Rashid, A.A., S. Habib, H.A. Lal, S.Z. Siddiqi and M. Arshad. 2003. Comparative efficacy of various insecticides to control gram pod borer (Helicoverpa armigera Hubner) on chickpea regional agriculture research institute, Bahawalpur, Punjab, Pakistan. Asian J. Plant Sci., 2(4): 403-405. https://doi.org/10.3923/ ajps.2003.403.405 
Reed, W. and C.S. Pawar. 1982. Heliothis: A global problem. In: Reed, W. and Kumble, V. (eds) Proceedings of international workshop on heliothis management, 15-20 November 1981. ICRISAT, Patancheru, pp. 9-14.

Reed, W., 1983. Estimation of crop losses due to insect-pests in pulses. Indian J. Ent., 2: 263-267.

Rivnay, E., 1962. Field crop pest in the near east. Netherlands Junk Publisher, The Hague, pp. 450. https://doi.org/10.1007/978-94-0171544-7

Roy, N.K. and P. Dureja. 1998. New eco-friendly pesticides for integrated pest management. Pesticides World, New Delhi, pp. 16-22.

Ruttoh, E.K., R.M.S. Mulwa, L. Ngode, L. Gohole, B. Towett, N. Njogu, S. Silim, G.V.R. Rao and P.K. Kimurto. 2013. Screening for host plant resistance to Helicoverpa armigera (Lepidoptera: Noctuidae) in selected chickpea (Cicer arientinum L.) genotypes in Kenya. Egerton J. Sci. Technol., 13: 39-55.

Sarwar, M., 2013. Exploration on resource of resistance in chickpea (Cicer arietinum L.) genotypes to gram pod borer Helicoverpa armigera (Hubner) (Lepidoptera). Afr. J. Agric. Res., 8(26): 3431-3435. https://doi. org/10.5897/AJAR11.2452

Sarwar, M., N. Ahmad and M. Toufiq. 2009. Host plant resistance relationships in chickpea (Cicer arietinum L.) against gram pod borer (Helicoverpa armigera Hubner). Pak. J. Bot., 41(6): 3047-3052.

Shabbir, M.Z., M. Arshad, B. Hussain, I. Nadeem, S. Ali, A. Abbasi, Q. Ali. 2014. Genotypic response of chickpea (Cicer arietinum L.) for resistance against gram pod borer (Helicoverpa armigera). Adv. Life Sci., 2(1). 23-30.

Shafique, M., S. Nadeem, M. Hamed, B.M. Atta and T.M. Shah. 2009. Performance of some advance desi chickpea genotypes against pod borer, Helicoverpa armigera (Hubner) resistance. Pakistan J. Zool., 41: 277-280.

Shahzad, K., A. Iqbal, S. Khalil and S. Khattak. 2005. Response of different chickpea (Cicer aritinum) genotypes to the infestation of pod borer (Helicoverpa armigera) with relation to trichomes. Res. J. Agric. Biol. Sci., 1(1): 120124.

Sharma, H.C., P.M. Gaur, S. Srinivasan and C.L.L. Gowda. 2014. Exploiting host plant resistance for pest management in chickpea. Legume
Perspect., 3: 25-28.

Sharma, M.L., H.S. Rai and M.L. Verma. 1997. Biopesticide for management of Helicoverpa armigera (Hubn.) in chickpea. Int. Chickpea Pigeon Pea Nerwsl., 4: 26-27.

Sharma, P.K., U. Kumar, S. Vyas, S. Sharma and S. Shrivastava. 2012. Monitoring of Helicoverpa armigera (Hubner) (Lepidoptera: Noctuidae) through pheromone traps in chickpea Cicer arietinum crop and influence of some abiotic factors on insect Population. J. Environ. Sci., 1: 44-46. https://doi.org/10.9790/2402-0154446

Sanap, M.M. and B.M. Jamadagni. 2005. Screening of chickpea for resistance to pod borer, Helicoverpa armigera (Hubner) at Rahuri, Maharashtra, India. Int. Chickpea Pigeon Pea Newsl., 12: 37-39.

Schulten, G.G.M., 1987. Challanges facing agricultural entomology in the tropics. Insect. Sci.Appl., 8: 397-405. https://doi.org/10.1017/ S1742758400022372

Singh, B.K. and R.P. Singh. 2007. Effect of host plant nutrition and pesticidal management on larval population of Helicoverpa armigera (Hubner) in chickpea Cicer arientium. India J. Ent., 69(4): 345-349.

Singh, G. and J.S. Balan. 1986. Host plant and natural enemies of Heliothis armigera in Haryana. Indian J. Ecol., 13: 175-178.

Singh, H., I. Singh and G. Mahajan. 2002. Effect of different dates of sowing on the incidence of gram pod borer (Helicoverpa armigera) on different cultivars of chickpea (Cicer arientinum). Agric. Sci. Dig., 22(4): 295-296.

Singh, O., C.L.L. Gowda, S.C. Sethi and S.S. Lateef. 1991. Inheritance of and breeding for resistance to Helicoverpa armigera pod borer in chick-pea. In: Golden jubilee symposium of indian society of genetics and plant breeding, 4-8 February 1991, New Delhi, India.

Sharma, H.C., 2005. Heliothis/ Helicoverpa management: Emerging trends and strategies for future research. Oxford and IBH Publishers, New Delhi

Thakur, P., 1998. Helicoverpa management through IPM approach on chickpea and pigeon pea. In: NARC/CLAN, Review and Planning meeting, Nawalpur, Sarlahi, Nepal, 25-27 May 1998, pp. 1-10.

Tripathi, A., R.C. Sharma, P.K. Dwivedi and M. Pandey. 2008. Effect of intercropping and 
insecticide on pod borer incidence in chickpea. J. Food Legumes, 21(3): 187-188.

Ujagir, R. and B.P. Khere. 1987. Preliminary screening of chickpea genotypes for susceptibility to Heliothis armigera (Hub.) at Pantnagar, India. Int. Chickpea Newsl., 17: 14. Ujjan, R.L., A.M. Ahmed, A.Z.A. Alhilfi, F.N. Khoso, A.M. Rahoo, I.A. Rajput and D.M. Soomro. 2019. Performance of pheromone traps at different heights for mass trapping of Helicoverpa armigera (Noctuidae: Lepidoptera) in chickpea field. Asian J. Agric. Biol., 7(4): 610-616.

Zalucki, M.P., G. Daglish, S. Firemponeng and P.H. Twine. 1986. The biology and ecology of Heliothis armigera (Hübner) and $\mathrm{H}$. punctigera
(Wallengren) (Lepidoptera: Noctuidae) in Australia: What do weknow? Aust. J. Zool., 42: 329-346. https://doi.org/10.1071/ZO9860779

Zohary, D., M. Hopf and E. Weiss. 2012. Domestication of plants in the old world: The origin and spread of domesticated plants in Southwest Asia, Europe, and the Mediterranean Basin. (Oxford University Press, 2012). https://doi.org/10.1093/ acprof:osob1/9780199549061.001.0001

Zhu, B.C., G. Henderson, F. Chen, H. Fei and R.A. Laine. 2001. Evaluation of vetiver oil and seven insect-active essential oils against Formosan subterranean termite. J. Chem. Ecol., 27(8): $1617-1625$. 